\title{
Molecular Epidemiology of Human Immunodeficiency Virus-1 in the State of Ceará, Northeast, Brazil
}

\author{
Sandra Rocha Gadelha, Nice Shindo/*, José Napoleão Monte Cruz**, \\ Mariza Gonçalves Morgado***, Bernardo Galvão-Castro/*/+
}

\begin{abstract}
Laboratório Avançado de Saúde Pública, Centro de Pesquisas Gonçalo Moniz-Fiocruz, Rua Valdemar Falcão 121, $40295-001$
Salvador, BA, Brasil *Escola Bahiana de Medicina e Saúde Pública, Fundação para o Desenvolvimento das Ciências, Salvador,

BA, Brasil **Laboratório Central de Saúde Pública, Fortaleza, CE, Brasil ***Laboratório de Aids e Imunologia Molecular,

Departamento de Imunologia, Instituto Oswaldo Cruz-Fiocruz, Rio de Janeiro, RJ, Brasil
\end{abstract}

We analyzed, by env and gag heteroduplex mobility assay, 149 human immunodeficiency virus (HIV-1) positive samples collected in Ceará during the year 2000. The prevalence of subtype B was $81.2 \%$ and the prevalence of subtype $F$ and B/F recombinants were both $2.7 \%$. Eight (5.4\%) and 12 (8\%) out of 149 samples showed indeterminate results in the env and gag analysis respectively. By FokI restriction fragment length polymorphism, $34 \%$ of the subtype B samples were identified as the typical Brazilian subtype B. In the present study, we identified HIV-1 subtype $F$ and $B / F$ in Ceará for the first time. Our results contribute to the understanding of HIV in Brazil, and may prove useful for the development of vaccine candidates.

Key words: human immunodeficiency virus - molecular epidemiology - Ceará - Brazil

Since the identification of human immunodeficiency virus (HIV) as the agent of the acquired immunodeficiency syndrome (AIDS), many studies have examined the molecular characteristics, mechanisms of gene expression, and genomic complexity of HIV.

HIV presents extensive genetic variability because of the high error rate of reverse transcriptase, the fast turnover of virions in HIV-infected individuals, and the possibility of recombination (Cornelissen et al. 1996, Malim \& Emerman 2001). The high genomic variability of HIV has important implications for diagnosis, treatment and prevention, as well as for epidemiological investigation ( $\mathrm{Hu}$ et al. 1996, Moore et al. 2001).

Two related viruses, HIV-1 and HIV-2, have been identified as etiologic agents of AIDS. Phylogenetic analyses of HIV-1 strains have revealed three distinct groups: M (major), $\mathrm{N}$ (new, non-M non-O), and $\mathrm{O}$ (outlier) (Moore et al. 2001). Within group $M$, at least 9 circulating genetic subtypes (A through $\mathrm{K}$ ) and 14 circulating recombinant forms have been identified (Thomson \& Nájera 2001).

The heteroduplex mobility assay (HMA), which is based on the env gene, has been widely used in Brazil as a tool for monitoring subtype distribution. Since intersubtype recombination is an important source of HIV-1 genetic variation, HMA subtyping focusing on two

Fiocruz is an UNAIDS Collaborative Center.

This work was partially supported by the National Coordination of STD/AIDS/UNDP/World Bank, (UNAIDS), Piaf/ Fiocruz/Ministry for Heath, and Brazilian Research Council (CNPq).

${ }^{+}$Corresponding author. Fax: +55-71-356.2255. E-mail: bgalvao@cpqgm.fiocruz.br

Received 5 September 2002

Accepted 25 March 2003 distinct HIV regions, env and gag, has been useful (Heyndrickx et al. 2000).

In Brazil, subtype B viruses cause the majority of HIV1 cases. Nevertheless, an increasing number of cases caused by non-B and recombinant viruses have been reported (reviewed by Morgado et al. 2002).

The majority of studies evaluating HIV diversity in Brazil have examined samples from the Southeast region. Until now, Bahia and Sergipe are the only states in the Northeast region where HIV-1 genetic characterization has been studied. The economic restrictions of this geographic region (which is the poorest of Brazil), combined with poor education and precarious public services, facilitate HIV transmission. In addition, sex tourism plays a significant role in the spread of HIV in many northeastern cities, leading to the introduction of new subtypes.

Among the nine states comprising the Northeast region of Brazil, Ceará ranks third in total number of AIDS cases, with 3,377 notified AIDS cases as of September 2001. Men represent $79 \%$ of the total cases, although an increasing number of female cases have been reported (Ministério da Saúde 2000).

In this study, we used HMA env and HMA gag for the first time in Brazil to evaluate the genetic diversity of HIV-1 in the state of Ceará and to detect recombinant forms.

\section{MATERIALS AND METHODS}

Study group - HIV-proviral DNA samples were obtained from peripheral blood cells of HIV-1 seropositive individuals and AIDS patients at São José Hospital (Fortaleza, CE). After signing an informed consent, 149 patients had $5 \mathrm{ml}$ of blood drawn. $\mathrm{CD}^{+} \mathrm{T}$ cell counts were determined by Facscount (Becton-Dickinson, CA, USA) in the Laboratório Central de Saúde Pública (Lacen)/Ceará. The samples were sent to the Laboratório Avançado de Saúde Pública (Lasp)/CPqGM/Fiocruz (Salvador) on the same day for further DNA processing. 
DNA preparation and polymerase chain reaction (PCR) amplification of HIV env and gag sequences - For subtype determination, proviral DNA samples were amplified using a nested PCR protocol as previously described (Delwart et al. 1993, Heyndrickx et al. 2000).

$H M A$ - PCR conditions and HMA subtyping were performed as described elsewhere (Delwart at al. 1993, Heyndrickx et al. 2000).

Restriction fragment length polymorphism (RFLP) determination - RFLP was performed as described previously (Morgado et al. 1998).

Statistical analyses - The chi-squared test was used to evaluate the relationship between HIV-1 subtype B genetic variants and demographic and clinical variables such as gender, clinical status, and $\mathrm{CD}^{+}$cell count. In addition, $95 \%$ confidence intervals (calculated using the exact binomial method) were used to determine the consistency of our study population with patients in the national and state AIDS databases. All analyses were performed using EpiInfo, version 6.0, and results with $\mathrm{p}<$ 0.05 were considered statistically significant.

\section{RESULTS}

Characterization of HIV-1 subtypes was conducted in a total of 149 patients from Ceará, $110(73.8 \%)$ men and $39(26.2 \%)$ women. Socio-demographic, clinical and laboratorial data of the studied group are summarized in the Table.

Samples of subtypes B, F and recombinant B/F were identified (Fig. 1). The prevalence of subtype $B$ was $81.2 \%$, while the prevalence of subtype $\mathrm{F}$ and recombinant $\mathrm{B} / \mathrm{F}$ were both $2.7 \%$. Eight $(5.4 \%)$ and $12(8 \%)$ out of 149 samples analyzed by HMA showed indeterminate results in the env and gag analysis respectively.

HMA env - B

B1 B2 B4 C1C2 D1 F1 F2 H I1 E1 B1 B4 C1 C2 D1 F1 F2 H

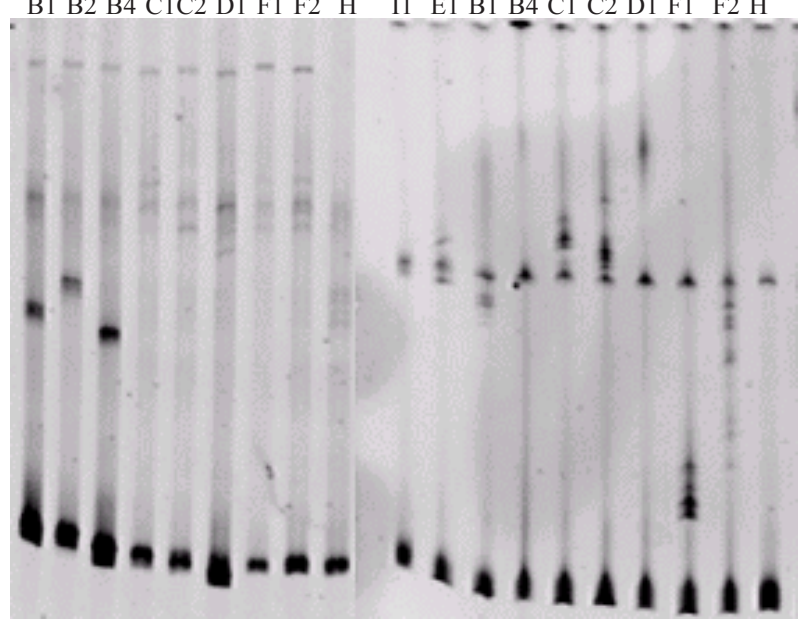

Fig. 1: gel representative of recombinant B/F. Molecular typing was done using env and gag heteroduplex mobility assay (HMA). The reference strains are indicated at the top of the gel. The env HMA was resolved by electrophoresis analysis at $250 \mathrm{~V}$ for $3 \mathrm{~h}$ on a nondenaturating $5 \%$ polyacrylamide gel in TBE buffer. The gag HMA was performed by electrophoresis analysis at $250 \mathrm{~V}$ for $2.5 \mathrm{~h}$ on a $5 \%$ polyacrylamide gel containing $20 \%$ urea in TBE buffer.
TABLE

Socio-demographic, clinical and laboratory characteristics of 149 human immunodeficiency virus type I positive individuals from Fortaleza, state of Ceará, Brazil

\begin{tabular}{ll}
\hline Characteristics & Nr of patients (\%) \\
\hline Gender & \\
Male & $110(73.8)$ \\
Female & $39(26.2)$ \\
Age & $36 / 33$ \\
Average (male / female) & $4(2.7)$ \\
$<10$ years & $2(1.3)$ \\
$11-20$ & $34(22.8)$ \\
$21-30$ & $61(41.0)$ \\
$31-40$ & $34(22.8)$ \\
$41-50$ & $7(4.7)$ \\
$51-60$ & $5(3.3)$ \\
NA & $112(75.2)$ \\
Origin & $34(22.8)$ \\
Urban area ( Fortaleza) & $3(2.0)$ \\
Rural area & \\
NA & $39(26.2)$ \\
CD4 T cell counts/mm & $38(39.0)$ \\
$<200$ & $47(31.5)$ \\
200-500 & $5(3.3)$ \\
> 500 & \\
NA & $92(61.7)$ \\
Clinical symptoms & $53(35.0)$ \\
Symptomatic & $5(3.3)$ \\
Asymptomatic & \\
NA & $121(81.2)$ \\
HMA gag/env subtyping & $4(2.7)$ \\
Benv/Bgag & $4(2.7)$ \\
Fenv/Fgag & $20(13.4)$ \\
Benv/Fgag & ND
\end{tabular}

NA: not available; ND: not determined for gag or env regions

Based on FokI RFLP, 34\% of the subtype B samples were identified as typical Brazilian subtype B (Fig. 2).

No association was identified between samples of North American/European subtype B samples, GWGR Brazilian subtype B samples and demographic or clinical variables (data not shown) (Morgado et al. 2002).

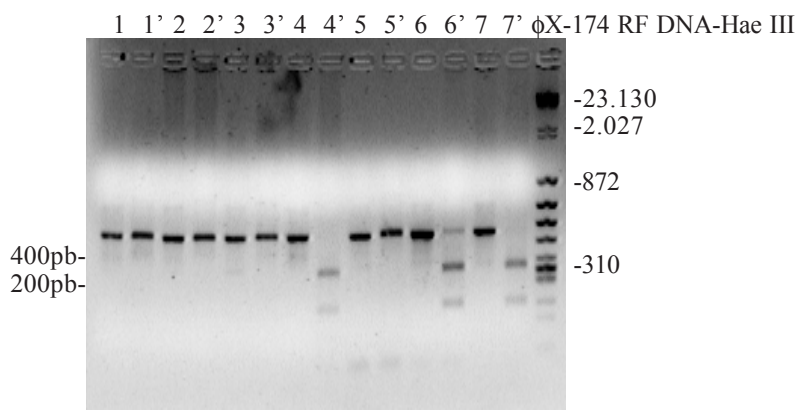

Fig. 2: restriction fragment length polymorphism of seven subtype $\mathrm{B}$ samples analyzed by env heteroduplex mobility assay, using FokI restriction enzyme. Sample without enzyme digestion was run in the far left lane as control. DNA samples were submitted to electrophoresis in $2.4 \%$ agarose gel using phi-X HaeIII as molecular weight marker. 


\section{DISCUSSION}

The demographic characteristics of this studied population from the state of Ceará are consistent with those of patients in the national and state AIDS databases.

We found a predominance of subtype B (94\%), which is similar to those found in previous evaluations of samples from the Southeast and Northeast regions of Brazil (reviewed by Morgado et al. 2002). In the present study we identified the presence of HIV-1 subtype F (2.7\%) and B/ $\mathrm{F}(2.7 \%)$ in Ceará for the first time.

The prevalence of subtype $\mathrm{F}$ in Ceará appears to be smaller than that described in the Southeast of Brazil (Brazilian Network for HIV-1 Isolation and Characterization 2000). In addition, subtype $C$ was not detected in any of our patients, which shows that the distribution of the HIV1 genetic subtypes assumes currently different patterns in different regions of the country (Morgado et al. 2002).

Several studies have found a high prevalence of env/ gag recombinants within HIV-infected populations (Cornellisen et al. 1996). Therefore, amplifying both gag HMA and env HMA allows us to provide a minimum estimate of the prevalence of the various subtypes and some of the recombinants of HIV-1.

A small percentage of samples did not show clear subtype identification after analysis with HMA (env, 5.4\% and $g a g, 8 \%$ ), which has also been reported in other studies using the same methodology (Delwart et al. 1993, Morgado et al. 1998, Heyndrickx et al. 2000). Sequencing is normally recommended for these cases, and this is part of our future goals.

The prevalence of the GWGR motif found in this study was $34.3 \%$. Other analyses using the same methodology found GWGR frequencies of $30-57 \%$, depending on the geographic area of investigation (Galvão-Castro et al. 1996, Morgado et al. 1998). Although the importance of the Brazilian subtype B in the AIDS epidemic is not entirely clear, the high prevalence of GWGR could be epidemiologically important and therefore relevant to vaccine development and/or testing in Brazil.

Our results could contribute to the understanding of HIV genetic polymorphism in Brazil, and may prove useful for the development of appropriate vaccines.

\section{REFERENCES}

Cornelissen M, Kampinga G, Zorgdrager F, Goudsmit J, UNAIDS Network for HIV-1 Isolation and Characteriza- tion 1996. Human immunodeficiency virus type 1 defined by env show high frequency of recombinants gag genes. $J$ Virol 70: 8209-8212.

Delwart EL, Shpaer EG, Louwagie J, McCutchan FE, Grez M, Rubsamen-Waigmann H, Mullins JI 1993. Genetic relationships determined by a DNA heteroduplex mobility assay: analysis of HIV-1 env genes. Science 262: 1257-1261.

Galvão-Castro B, Couto-Fernandez JC, Mello MA, Linharesde-Carvalho MI, Castello-Branco LR, Bongertz V, Ferreira PCP, Morgado M, Sabino E, Tanuri A, The Brazilian Network for the HIV-1 Isolation and Characterization 1996. A nationwide effort to systematically monitor HIV-1 diversity in Brazil: preliminary results. Mem Inst Oswaldo Cruz 91: 335-338.

Heyndrikx L, Janssens W, Zekeng L, Musonda R, Anagonou S, Van Der Awera G, Coppens S, Vereecken K, De White K, Van Rampelbergh R, Kalhindo M, Morison L, McCuthan FE, Carr JK, Albert J, Essex M, Goudsmit J, Asjo B, Salminen M, Buvé A, Study Group on Hetrogeneity of HIV Epidemics in African Cities, Van Der Groen G 2000. Simplified strategy for detection of recombinant HIV-1 group $\mathrm{M}$ isolates by gag/env heteroduplex mobility assay. J Virol 74: 363-370.

$\mathrm{Hu}$ DJ, Dondero TJ, Rayfield MA, George JR, Schochetman G, Jaffe HW, Luo C, Kalish ML, Weniger BG, Pau C, Schable CA, Curran JW 1996. The emerging genetic diversity of HIV. Jama 275: 210-216.

Malim MH, Emerman M 2001. HIV-1 sequence variation: drift, shift and attenuation. Cell 104: 469-472.

Ministério da Saúde 2000. Context of AIDS in Ceará. Available in: http://www.aids.gov.br.

Moore JP, Parren PWHI, Burton DR 2001. Genetic subtypes, humoral immunity, and human immunodeficiency virus type 1 vaccine development. J Virol 75: 5721-5729.

Morgado MG, Guimarães ML, Galvão-Castro B 2002. HIV-1 polymorphism: a challenge for vaccine development - A review. Mem Inst Oswaldo Cruz 97: 143-150.

Morgado MG, Guimarães ML, Gripp CBG, Costa CI, Neves I, Veloso VG, Linhares-Carvalho MI, Castello-Branco LR, Bastos FI, Kuiken C, Castilho EA, Galvão-Castro B, Bongertz V, Evandro Chagas Hospital AIDS Clinical Research Group 1998. Molecular epidemiology of HIV-1 in Brazil: high prevalence of HIV-1 subtype B and identification of an HIV-1 subtype D infection in the city of Rio de Janeiro, Brazil. J AIDS Hum Retrovirol 18: 488-494.

Thomson MM, Nájera R 2001. Travel and the introduction of human immunodeficiency virus type 1 non-B subtype genetic forms into western countries. Clin Infect Dis 32: 17321737. 